Maurer School of Law: Indiana University

Digital Repository@Maurer Law

Indiana Law Journal

Volume 87 | Issue 1

Article 15

Winter 2012

\title{
Claim-Suppressing Arbitration: The New Rules
}

David S. Schwartz

University of Wisconsin - Madison, dsschwartz@wisc.edu

Follow this and additional works at: https://www.repository.law.indiana.edu/ilj

Part of the Dispute Resolution and Arbitration Commons, and the Labor and Employment Law

Commons

\section{Recommended Citation}

Schwartz, David S. (2012) "Claim-Suppressing Arbitration: The New Rules," Indiana Law Journal: Vol. 87 : Iss. 1 , Article 15.

Available at: https://www.repository.law.indiana.edu/ilj/vol87/iss1/15

This Symposium is brought to you for free and open access by the Law School Journals at Digital Repository @ Maurer Law. It has been accepted for inclusion in Indiana Law Journal by an authorized editor of Digital Repository@Maurer Law. For more information, please contactrvaughan@indiana.edu.

\section{$\Psi$}

JEROME HALL LAW LIBRARY

INDIANA UNIVERSITY

Maurer School of Law
Bloomington 


\title{
Claim-Suppressing Arbitration: The New Rules ${ }^{\dagger}$
}

\author{
DAVID S. SCHWARTZ
}

\begin{abstract}
Binding, pre-dispute arbitration imposed on the weaker party in an adhesion contract-so-called "mandatory arbitration"-should be recognized for what it truly is: claim-suppressing arbitration. Arguments that such arbitration processes promote access to dispute resolution have been refuted and should not continue to be made without credible empirical support. Drafters of such arbitration clauses are motivated to reduce their liability exposure and, in particular, to eliminate class claims against themselves. Furthermore, claim-suppressing arbitration violates two fundamental principles of due process: it allows one party to the dispute to make the disputing rules; and it gives the adjudicative role to a decision maker with a financial stake in the outcome of key jurisdictional decisions-that is to say, arbitrators have authority to decide their own power to decide the merits-a question in which they have a financial stake. The Supreme Court has facilitated this doctrine through a series of poorly reasoned decisions in which the Court's liberal wing has been particularly inept at seeing the stakes for consumer and employee plaintiffs. Exploiting Justice Breyer's incoherent line of majority opinions attempting to identify "gateway" issues, the conservative Court majority has recently insulated all questions of enforceability of arbitration clauses from judicial review and is on the verge of allowing corporate defendants to immunize themselves from class actions through the use of arbitration clauses.
\end{abstract}

\section{INTRODUCTION}

It's time to be candid and call this thing what it is. We can begin by stating what it is not. It is not Alternative Dispute Resolution (ADR). "Alternative dispute resolution," as we mean that term when we say it in its rosy-hued form, does not mean every conceivable alternative to litigation in court. Otherwise, ADR would be understood to include dueling, extortion, and assassination. What we mean by ADR is a dispute-resolving process that is either meaningfully voluntary at the beginning or nonbinding at the end.

It is not a justice system. While a justice system could, in theory, be made up partly or even wholly by binding arbitration, binding arbitration imposed unilaterally by the defendant is another matter. It is not demonstrably fair. It is not imposed to promote small claims or otherwise help the "little guy" who is excluded from meaningful access to the courts.

Finally, let's stop calling it "mandatory arbitration," that bloodless, hypertechnical, and misleading term. "Mandatory" implies that the arbitration process is binding on both sides, but that is less than half true: it is voluntarily chosen by the defendant, who drafts the arbitration clause, and "mandatory" only on the party who doesn't want it, typically the plaintiff.

$\dagger$ Copyright () 2012 David S. Schwartz.

* Professor of Law, University of Wisconsin Law School. 
So what is this thing? It is claim-suppressing arbitration. It is designed and intended to suppress claims, both in size and number.

The Arbitration Fairness Act should be passed because consumer and employment disputes are too important a henhouse to be governed by contracts written by foxes - even slightly regulated foxes. Far from correcting the injustice arising from its own Federal Arbitration Act (FAA) interpretations, the Supreme Court is poised to put the finishing touches on converting the FAA into a radical claim-suppressing statute.

\section{No WAY TO DESIGN A DiSPUTE SySTEM}

\section{A. "Mandatory Arbitration" Is Claim-Suppressing Arbitration}

The compelling logic of what is commonly called "mandatory arbitration" is that it is intended to suppress claims. In a recent article, I demonstrated that the economically rational motivation for employers and sellers to write pre-dispute arbitration agreements into their adhesion contracts for employment and sales is to keep "high-cost/high-stakes" claims out of court. ${ }^{1}$ High-cost claims are those in which proof is relatively complex and the pre-litigation distribution of evidence is largely in the possession of the defendant. Therefore, extensive discovery is required for the plaintiff to meet his burden of proof, and the potential litigation costs are relatively high. High-stakes claims are those in which the liability payoff (including both damages and statutory attorneys' fees, if any) is relatively high. High-cost/high-stakes claims include, among other things, factually or legally complex individual employment disputes and both employment and consumer class actions. $^{2}$

No other configuration of cases, categorized by costs and stakes, can motivate the employer-seller to adopt a pre-dispute arbitration regime. "Low-stakes" cases (whether low or high cost) will tend to be those for which claimants have a hard time obtaining contingency fee counsel. According to Professor Sherwyn, Professor Estreicher, and others, employer/seller defendants tend to prefer to litigate lowstakes cases as a deterrent "war of attrition" strategy (my term), in the hope of driving up the plaintiffs' process costs beyond what the low liability stakes would justify. ${ }^{3}$ Meanwhile, "low-cost/high-stakes" cases are those that both sides would be willing to arbitrate. Defendants do not want to avail themselves of litigation to drive up the costs since that will merely turn the case into a high-cost/high-stakes

1. David S. Schwartz, Mandatory Arbitration and Fairness, 84 Notre Dame L. Rev. $1247,1264-83$ (2009).

2. $I d$.

3. See Samuel Estreicher, Saturns for Rickshaws: The Stakes in the Debate over Predispute Employment Arbitration Agreements, 16 OHIO ST. J. ON DisP. ResOL. 559, 567 (2001); David Sherwyn, Samuel Estreicher \& Michael Heise, Assessing the Case for Employment Arbitration: A New Path for Empirical Research, 57 STAN. L. ReV. 1557, 1579-80 (2005); David Sherwyn, Because It Takes Two: Why Post-Dispute Voluntary Arbitration Programs Will Fail to Fix the Problems Associated with Employment Discrimination Law Adjudication, 24 BerKeley J. EMP. \& LAB. L. 1, 32 (2003). 
case, which defendants prefer to arbitrate anyway. ${ }^{4}$ More specifically, defendants understand that driving up the costs will probably not deter plaintiffs, who are likely to stay in the game to pursue the high stakes. ${ }^{5}$

Why would employers trade away their litigation preference in low-cost cases in order to force high-cost/high-stakes cases out of litigation and into arbitration? That, after all, is the net result of a pre-dispute arbitration regime, at least if one does not carve out categories of cases. Presumably, defendants calculate that they save more in total cost by arbitrating the high-cost/high-stakes claims than they save by deterring the low-stakes claims.

Where does this cost savings come from? Arbitration supporters would have us believe that it is all process costs. Liability outcomes, they argue, are the same in arbitration and litigation - plaintiffs do just as well in both forums - and they cite a handful of sketchy, methodologically unsound studies to back up their point. ${ }^{6}$ (As for the studies that purport to show that arbitration outcomes are as good as litigation ones, let me propose a new rule [with apologies to Bill Maher ${ }^{7}$ ]: no more citing the arbitration studies unless and until they have been fully rehabilitated as methodologically sound. ${ }^{8}$ ) In other words, arbitration supporters necessarily imply

4. See Estreicher, supra note 3, at 567; Sherwyn, supra note 3, at 32.

5. Plaintiffs, for their part, would have an incentive to rely on the simpler procedures and presumably lower process costs of arbitration: assuming my definitional assumption holds, that "low cost" implies a favorable evidence distribution for the claimant and hence less need for costly discovery processes, low-cost/high-stakes claimants have no incentive to prefer litigation (unless they have reason to believe that litigation outcomes are better than arbitration outcomes).

6. See, e.g., National Arbitration Forum, The CASE for Pre-Dispute Arbitration AgreEmENTS: EFFECTIVE AND AFFORDABle ACCESS to JustiCE FOR CONSUMERs: EMPIRICAL StUdies \& SuRvey Results (2004) 1 (2004) (concluding that consumers pay more in process costs and obtain less favorable results in litigation compared to arbitration); Michael Delikat \& Morris M. Kleiner, Comparing Litigation and Arbitration of Employment Disputes: Do Plaintiffs Better Vindicate Their Rights in Litigation?, A.B.A. Conflict MGMT., Winter 2003, at 1, 11 (claiming to have shown "the process benefits of faster dispute resolution and lower transactional costs" in arbitration compared to litigation); Estreicher, supra note 3, at 563 ("[T] he sheer costs of defending a litigation and the risks of a jury trial create considerable settlement value irrespective of the substantive merits of the underlying claim."); Lewis L. Maltby, Private Justice: Employment Arbitration and Civil Rights, 30 Colum. Hum. RTS. L. REv. 29, 48 (1998) (claiming that those who arbitrate fare better than those who litigate); David Sherwyn, J. Bruce Tracey \& Zev J. Eigen, In Defense of Mandatory Arbitration of Employment Disputes: Saving the Baby, Tossing Out the Bath Water, and Constructing a New Sink in the Process, 2 U. PA. J. LAB. \& EMP. L. 73, 140 n.377 (1999) (arguing that mandatory arbitration reduces nuisance suits). For a summary and methodological critique of this pro-arbitration research, see Schwartz, supra note 1, at 1250 51, 1283-97.

7. See BillMaher.com, http://www.billmaher.com/.

8. Among other things, I would like to see someone address the criticisms I have made. The short version is this: the handful of primary statistical studies cited as supporting the claim that arbitration outcomes are as good as litigation outcomes, with one exception, are partisan studies entitled to the same respect we give studies funded by the tobacco industry showing that cigarettes do not cause cancer. See Schwartz, supra note 1, at 1283-97. The one exception is the study published by Eisenberg and Hill in the American Arbitration 
that the various procedures that make litigation more expensive than arbitration-in particular, discovery-produce no net gains for plaintiffs. These procedures are "outcome neutral," and, because costly, they are a mere wasteful transaction cost. What were we thinking all these years to allow plaintiffs to have discovery?

That implied assertion seems absurd on its face. Indeed, no arbitration supporter in academia or the judiciary has dared make that sweeping claim; all are careful to stop well short of doing so. In fact, discovery processes are not outcome neutral. Nor are they linear in relationship to outcomes: it is not the case that every dollar of discovery leads to an even increment in additional recovery. On the contrary, discovery is an investment that pays no dividend at all until crossing a line representing the burden of production. Until a plaintiff has enough evidence to get past summary judgment, he has a losing case of little or no settlement value. ${ }^{9}$ Defendants' keen interest in arbitration of high-cost/high-stakes cases is not to reap a "peace dividend" of purely process costs, but in the hope that tamping down process costs-primarily by severely limiting discovery-will translate into tamping down ultimate liability costs. It is an interest in claim suppression.

The motivation of employers and sellers to use arbitration as a claimsuppressing technique is borne out by their positions with regard to class actions. Nothing is more claim-suppressing than a ban on class actions, particularly in cases where the economics of disputing make pursuit of individual cases irrational. Two paradigm examples are all too common. In the consumer setting, low-dollar-value rip-offs that generate large revenues because practiced on a wide scaleunauthorized charges to credit card holders for unsolicited "credit insurance," for example - can go entirely unremedied without a class action. Small, quotidian violations of wage and hour laws by mass employers would likewise go unremedied if relegated to individual suits. Professor Eisenberg has shown that barring class actions has become a primary factor in companies' choice to use pre-dispute arbitration. ${ }^{10}$ Defendants have been fighting that battle in the courts for the past decade and are on the very edge of victory.

Association magazine. Theodore Eisenberg \& Elizabeth Hill, Arbitration and Litigation of Employment Claims: An Empirical Comparison, DisP. Resol. J., Nov. 2003-Jan. 2004, at 44. It pains me to say this, but I feel it needs to be said, given the frequency with which the piece is cited and the cachet it gets from Professor Eisenberg's sterling reputation: the Eisenberg and Hill study is shoddy work that is unworthy of Professor Eisenberg, an outstanding empirical researcher with a well-deserved reputation for methodological rigor. Its poor quality and misleading conclusions warrant retraction. I have shown in painstaking detail how the data used in their analysis was essentially cherry-picked to exclude the great majority of high-cost/high-stakes cases while disproportionately including cases brought by apparently elite workers with individually negotiated employment contracts. The study selected a patently unrepresentative sample of arbitration cases that are very likely to inflate the arbitration results. See Schwartz, supra note 1, at 1297-1315.

9. Schwartz, supra note 1, at 1274-80.

10. See Theodore Eisenberg, Geoffrey P. Miller \& Emily Sherwin, Arbitration's Summer Soldiers: An Empirical Study of Arbitration Clauses in Consumer and Nonconsumer Contracts, 41 U. Mich. J.L. REFORM 871, 875-76 (2008). Professor Sternlight demonstrated some time ago that corporate defense attorneys were deploying arbitration clauses for the express purpose of creating a "shield" against class actions. Jean R. Sternlight, As Mandatory Binding Arbitration Meets the Class Action, Will the Class Action Survive?, 42 WM. \& MARY L. REV. 1, 8-10 (2000). 


\section{B. Traditional Versus Claim-Suppressing Arbitration}

The FAA was designed to enforce arbitration agreements entered into by parties who had substance-neutral and remedy-neutral reasons for preferring nonjudicial, but binding, dispute resolution. ${ }^{11}$ The great error from the 1980 s to today has been the Supreme Court's reinterpretation of that statute to extend the pre-dispute arbitration option to parties whose intention is to suppress claims. ${ }^{12}$

Arbitration under the FAA was not intended to be a claim-suppressing vehicle for the benefit of wealthier parties in one-sided contracts. As Professor Stone shows in her leading account of the history of pre-dispute arbitration agreements, "[T]he FAA was enacted in response to the commercial community's desire to strengthen the internal arbitration systems of trade associations." ${ }^{13}$ Arbitration would control the costs of disputing and, therefore, the cost of doing business; rules of decision would be supplied by industry insiders according to the standards and norms of the particular trade rather than the general and arcane contract rules created by judges; and disputes could be kept "in the family" rather than put on expensive public display in the courts. ${ }^{14}$

On the other hand, classical arbitration pursuant to pre-dispute agreements does not fit nearly so well when the dispute is between parties who are not part of the "[s]elf-[r] egulat[ing] . . . [n]ormative [c]ommunity" of a trade association. ${ }^{15}$ There are less likely to be agreed private norms to supply rules of decision, less mutual interest in keeping the dispute "within the family," a greater likelihood of a public interest in the dispute, and a greater need to resort to the rules of decision created by public institutions. Moreover, while cheap and fast dispute resolution is all well in theory, the "insider vs. outsider" dispute is more likely to involve disparities of wealth and knowledge for which the presence of lawyers-though more expensive - can make the playing field more level.

All of these limitations of traditional private arbitration were very much in the minds of the Supreme Court justices when they held in Wilko v. Swan ${ }^{16}$ that

11. See Katherine Van Wezel Stone, Rustic Justice: Community and Coercion Under the Federal Arbitration Act, 77 N.C. L. REv. 931, 994-95 (1999) (describing the history in detail); see also David S. Schwartz, If You Love Arbitration, Set it Free: How "Mandatory" Undermines "Arbitration," 8 NEV. L.J. 400, 402-06 (2007).

12. See David S. Schwartz, Enforcing Small Print to Protect Big Business: Employee and Consumer Rights Claims in an Age of Compelled Arbitration, 1997 WIS. L. REV. 33, 89110.

13. Stone, supra note 11, at 994.

14. See Clarence F. Birdseye, Arbitration And Business Ethics 35 (1926); LAWrence M. Friedman, A History of AMERicAn LAW 45-46 (2d ed. 1985); Reginald Alleyne, Delawyerizing Labor Arbitration, 50 Oніо ST. L.J. 93, 94 (1989); William Catron Jones, Three Centuries of Commercial Arbitration in New York: A Brief Survey, 1956 WASH. U. L.Q. 193, 212; Philip G. Phillips, A General Introduction, 83 U. PA. L. ReV. 119, 126 (1934); Joseph Antonio Raffaele, Lawyers in Labor Arbitration, ARB. J., Sept. 1982, at 14, 15; Schwartz, supra note 12, at 70-73; Stone, supra note 11, at 976-79; Earl S. Wolaver, The Historical Background of Commercial Arbitration, 83 U. PA. L. ReV. 132, 144 (1934).

15. Stone, supra note 11 , at 994.

16. 346 U.S. 427 (1953), overruled by Rodriguez de Quijas v. Shearson/Am. Express, Inc., 490 U.S. 477 (1989). 
arbitration was an unsuitable vehicle for the resolution of claims under public regulatory statutes. In overruling Wilko, the Court said, not that classical arbitration was adequate for public law disputes after all, but rather that arbitration itself had changed - by the introduction of more lawyers as arbitrators and by the increasing judicialization of arbitration processes. ${ }^{17}$

Overruling Wilko and the public policy exception to pre-dispute arbitration enforcement $^{18}$ was a mistake. The existence of statutes to regulate the relationships of employer-employee, consumer-seller, franchisor-franchisee, and the like indicate an inequality of bargaining power that vitiates meaningful consent to secondary contract terms like arbitration agreements. Moreover, as will be explored below, the motivation to use dispute-control provisions in adhesion contracts is invariably to suppress claims.

But even if one accepts the premise that the FAA applies to claim-suppressing arbitration clauses, the Supreme Court, particularly the various liberal justices, have been grievously short-sighted, inattentive, or plain dense in failing to draw distinctions between claim-suppressing arbitration clauses and commercially reasonable ones. At a minimum, the Court should have been far more cautious about applying rules from cases involving disputes between substantial commercial entities with roughly equal power to bargain over arbitration terms - the parties in the recent Stolt-Nielsen case are illustrative ${ }^{19}$ - to cases involving adhesion contracts imposed on employees and consumers. Likewise, rules arising out of labor arbitration, where the union has much greater bargaining power than an individual employee, do not always translate appropriately into the adhesion contract setting. ${ }^{20}$ Yet the Court has invariably treated these situations as interchangeable ${ }^{21}$ - a mistake whose full implications are only now becoming manifest. $^{22}$

17. Rodriguez de Quijas v. Shearson/Am. Express, Inc., 490 U.S. 477, 484 (1989); see Schwartz, supra note 11, at 406-12, 417-19.

18. See Schwartz, supra note 12, at 95-103; see also infra Part II.A.

19. See Stolt-Nielsen S.A. v. Animalfeeds Int'l Corp., 130 S. Ct. 1758 (2010); see also infra Part II.B.

20. See, e.g., Roberto L. Corrada, The Arbitral Imperative in Labor and Employment Law, 47 CATH. U. L. REV. 919, 932 (1998). Professor Corrada argued that, despite legislative history in the 1991 Civil Rights Act that "cautions against permitting compulsory arbitration of statutory claims," the same "arbitral imperative" that led the Court to embrace labor arbitration in the 1950s would lead to parallel developments in private employment arbitration under Gilmer. Id. at 932-33. His analysis has proven remarkably prescient. See id. at 936-39.

21. See, e.g., Green Tree Fin. Corp. v. Bazzle, 539 U.S. 444, 456 (2003) (applying "arbitrability" rules from labor cases to adhesive consumer contract); PacifiCare Health Sys. v. Book, 538 U.S. 401, 404 (2003) (applying arbitrability result in Vimar Seguros y Reaseguros, S.A. v. M/V Sky Reefer, 515 U.S. 528 (1995), a business-versus-business case, to an adhesive consumer contract).

22. See infra Part II.B. 


\section{What We Learned in Law School About "Due Process"}

Two glaring violations of very basic due process principles underlie arbitration law. The principles are that: (1) parties with a financial stake in the outcome cannot be neutral adjudicators; and (2) a party to a dispute is not given the exclusive right to decide key dispute resolution rules simply because he is wealthier and more powerful.

Claim-suppressing arbitration violates both of these principles. I find it disappointing that courts and commentators schooled in U.S. constitutionalism and the rule of law are not continually shocked and appalled by this central feature of FAA jurisprudence. I can only attribute our collective blasé attitude to one of two mental responses. One is the situational ethics of legal sophisticates who are happy to find "consent" in any adhesion contract term that seems to them consistent with sound commercial policy. ${ }^{23}$ The other is a kind of jurisprudential Stockholm Syndrome: the moral objections have been whipped out of us claim-suppressing arbitration opponents to the point where we are grateful and celebratory every time a court creates a tiny, narrow exception to the general regime of claim-suppressing arbitration.

\section{Financial Stakes}

Disputes over arbitration and FAA interpretation-in particular, the entire twenty-year debate over claim-suppressing arbitration - are not disputes about the underlying merits of cases but over the question "who decides?" In a fairer and more plain-spoken era, the Supreme Court expressly recognized that "who decides" can affect the substantive outcome. ${ }^{24}$ So the procedural question-deciding who decides - is a decision that matters and a decision worth contesting. Will the merits be decided in arbitration or in court?

The Supreme Court, in a long and tortuous sequence of decisions, beginning with Prima Paint Corp. v. Flood \& Conklin Manufacturing Co. ${ }^{25}$ in 1967 and continuing to the present day, has increasingly empowered the arbitrator to decide "who decides," narrowing the role of the court to one of determining the enforceability of arbitration agreements only where the agreement is silent on the "who decides" question. As will be discussed further below, Rent-A-Center $v$. Jackson, ${ }^{26}$ decided last term, authorizes would-be defendants to add a simple contract term that would deprive a court of any power to review the enforceability

23. For an excellent appraisal of consent analysis in court decisions and academic commentary on arbitration, see Jeffrey W. Stempel, Bootstrapping and Slouching Toward Gomorrah: Arbitral Infatuation and the Decline of Consent, 62 BROOK. L. REV. 1381 (1996).

24. See, e.g., Bernhardt v. Polygraphic Co. of Am., 350 U.S. 198 (1956) (concluding that compelling arbitration is outcome-determinative for purposes of Erie Doctrine); Wilko v. Swan, 346 U.S. 427, 435-37 (1953); see also Boyd v. Grand Trunk W. R.R. Co., 338 U.S. 263 (1949) (voiding adhesive venue clause in employment contract as applied to an action under the Federal Employers' Liability Act).

25. Prima Paint Corp. v. Flood \& Conklin Mfg. Co., 388 U.S. 395 (1967).

26. 130 S. Ct. 2772 (2010). 
of an arbitration agreement. A court-state or federal-presented with an arbitration agreement containing a properly-drafted Rent-A-Center clause will have no discretion but to enforce the clause. This sweeping-breathtaking, reallyimplication of Rent-A-Center escaped even the dissenters. ${ }^{27}$

The bottom line is that all questions about whether the arbitration agreement is enforceable are to be decided by the arbitrator. It has not escaped the notice of some of us that an arbitrator has a financial stake in the outcome of this decision. ${ }^{28}$ If the arbitrator decides that the arbitration agreement is unenforceable, he loses income. Assume a modest case: ten hours of prehearing work, fifteen hours of hearing, and five hours to write up an award. Such a case can easily mean $\$ 10,000$ or more of income to the arbitrator.

So what that this jurisdictional decision is not a merits decision. It is a contested decision, one of significant import to the parties. It is deemed so important that -at least when arbitration is denied by a court - the decision is immediately appealable. $^{29}$

Perhaps there are cases in which an arbitrator has determined that the agreement is unenforceable. If you were forced to bet, however, how would you bet most of these enforceability issues are decided? In the analogous situation, where arbitrators are asked to decide whether an ambiguous or "silent" arbitration clause permits certification of an arbitral class action, it appears that arbitrators have tended to act consistently with their financial interest by deciding to certify class actions - thus guaranteeing themselves months of full employment. ${ }^{30}$ Indeed, that practice has goaded the Supreme Court into stopping it in Stolt-Nielsen, discussed below. $^{31}$

The idea that a decision will be rendered by a financially interested adjudicator is positively medieval.

The financial bias of purported "neutrals" does not start or end with the arbitrator's financial stake in finding in favor of his own jurisdiction. It infects the entire system. Claim-suppressing arbitration is a mass phenomenon. Employers impose it on their entire workforce; commercial sellers and service providers impose it on their entire customer base. If there has ever been an instance of an individual worker imposing arbitration on an employer or an individual consumer imposing arbitration on a large corporate seller-I'm talking about ordinary folks, not the incoming CEO of Bank of America or Bill Gates buying a vacation homeI'd love to hear about it.

What this means is that the vehicle for claim-suppressing arbitration is the standard-form adhesion contract. And what that means is that the drafter of the adhesion contract - the employer or the commercial seller-has the sole and exclusive right to choose arbitration. That, in turn, means that pre-dispute

27. See infra Part II.B.

28. See, e.g., Richard C. Reuben, Constitutional Gravity: A Unitary Theory of Alternative Dispute Resolution and Public Civil Justice, 47 UCLA L. REv. 949, 1063 (2000).

29. See Federal Arbitration Act, 9 U.S.C. $\$ 16$ (2006).

30. See Stolt-Nielsen S.A. v. Animalfeeds Int'l Corp., 130 S. Ct. 1758, 1767 (2010); Green Tree Fin. Corp. v. Bazzle, 539 U.S. 444, 449 (2003).

31. See Stolt-Nielsen, 130 S. Ct. at 1767 (discussed infra text accompany notes 97-112). 
arbitration, as a service, is purchased solely and exclusively (in this context) by the employer-seller - that is, the claim suppressor.

From the vantage point of the arbitration provider then, arbitration is a service it sells to the claim suppressor. The consumer or employee is merely a third-party "beneficiary" (if that is the word) of that primary customer-service relationship. There is no economic incentive for arbitration providers to make pre-dispute arbitration attractive to employee-consumers: they never purchase the service because, in effect, they can't purchase the service. But there is naturally an economic incentive for arbitration providers to make pre-dispute arbitration attractive to claim-suppressors. ${ }^{32}$

Academics don't like to attack the American Arbitration Association (AAA). AAA sponsors conferences and research, and it sends nice people to conferences sponsored by academics. AAA folks are always polite and friendly. AAA takes the high road in trying to run arbitration in a fair way, and it takes the lead in trying to tweak arbitration rules to make them less unfair. In short, AAA is the good cop in a good-cop/bad-cop system. I have two points to make about this. First, let's not forget the National Arbitration Forum. ${ }^{33}$ Second, buyers of claim-suppressing arbitration consist entirely of entities desiring to suppress claims. If arbitration providers, including AAA, refuse entirely to cater to the wants of those customers, the market dries up. AAA, like the other arbitration providers, has an incentive to stay just a step ahead of legal fairness requirements, perhaps, but to make arbitration as defendant friendly as possible without failing a judicial sniff test. Moreover, AAA, like other arbitration providers, oversees arbitrator selection: it determines who is in its pool of arbitrators; and, from that pool, it will provide a short list to disputants under its arbitrator-selection protocol. When an important customer sits down for dinner at a restaurant, do you think the manager is indifferent about who will wait on the table?

32. I hope no one is now retorting, "But AAA is a nonprofit!" So are hospitals, but they advertise, compete with one another for customers, seek to grow their business, and give their management substantial salaries and bonuses. In other words, the incentive of this model of nonprofits to be solicitous of their customers is no different from that of profitmaking firms. AAA's 2009 Annual Report illustrates this point eloquently: AAA in 2009 “identified and leveraged new growth opportunities." AM. ARB. Ass'N, 2009 PRESIDENT's LetTer \& Financial Statements 1 (2009). With over $\$ 100$ million in assets at the end of 2008, AAA had an annual "public education" (i.e., advertising) budget between $\$ 1$ and $\$ 2$ million dollars. Am. Arb. Ass'n, President's Letter \& FinAnCiAl StAtements (2008).

33. The National Arbitration Forum was sued by the state of Minnesota for consumer fraud. The National Arbitration Forum conducts consumer debt collection arbitrations, yet, according to the complaint, is owned by a hedge fund, which in turn owns substantial interests in debt-collection businesses. Complaint, Minnesota v. National Arbitration Forum (filed in the Fourth Judicial District Court of Minnesota on July 14, 2009) (not assigned a docket number due to a July 17, 2009 settlement), available at http://www.ag.state.mn.us/PDF/PressReleases/SignedFiledComplaintArbitrationCompany.p df. As part of a settlement of that suit, the National Arbitration Forum agreed to cease administering credit card and consumer arbitrations in Minnesota. Wade Goodwyn, Arbitration Firm Settles Minnesota Legal Battle, NPR (July 23, 2009), http://www.npr.org/templates/story/story.php?storyId=106913248. 
This argument is not intended to — and reasonably should not—offend individual arbitrators, some of whom are my colleagues. Indeed, those who take umbrage at my suggestion of financial bias entirely miss the point. I am not suggesting that arbitrators - either as a class or any particular individuals - are venal or otherwise prone to acting in bad faith. The point is that the system of arbitration as a structural matter creates financial incentives to decide questions of arbitrator jurisdiction ("who decides") and even merits issues favorably toward those who pay them. That argument does not depend at all on individual good faith or bad faith. The objections I frequently hear at conferences from arbitrator colleagueswhich boil down to "but I am a fair person!"-were conclusively answered long ago by James Madison: "If men were angels, no government would be necessary. If angels were to govern men, neither external nor internal controls on government would be necessary." 34 The due process principle that the role of neutral adjudicator will not be given to a financially interested party is, in effect, one of those necessary external controls. I merely suggest that even arbitrators are not angels.

\section{Disputing Rules}

Every eight-year-old kid has the good sense to understand that permitting the playground bully to make the "dispute resolution" rules - "we'll arm wrestle, and if I win, I get to keep your lunch money"-is "no fair." This principle has somehow eluded the legal establishment's understanding when it comes to pre-dispute arbitration.

Binding arbitration is a dispute resolution process backed up by statutes that for all intents and purposes convert its judgments into those of a court. Though private, it is an adjunct to government. Generally speaking, our governmental institutions are statutory, not contractual, creations. There is no constitutional justification for a rule that "the wealthier party has the sole and exclusive right to make the rules."

To be sure, wealth commands advantages in virtually all social and political arenas, including legislative. But sometimes sheer numbers win out, and wealth is regulated.

Arbitration supporters have argued that claim-suppressing arbitration is politically and constitutionally sound because of the presence of two factors: (1) it is outcome neutral relative to litigation; and (2) it leads to greater access to dispute resolution for "the common folk." 35 The latter argument has been summed up by Professor Estreicher in a folksy homily in which litigation is "Cadillacs for the few" and "Rickshaws for the many," while arbitration is Saturns for everyone. ${ }^{36}$ Regrettably, Saturn is out of business. But let's not take the metaphor too literally: the problem acknowledged by Professors Estreicher and Sherwyn is that this economy car (Saturn or what have you) is only available to the many by enforcing

34. The Federalist No. 51 (James Madison).

35. See Schwartz, supra note 1, at 1250-51.

36. Estreicher, supra note 3, at 563-64. 
the defendants' own arbitration agreement against him—-hoisting him on his own petard, if you will. ${ }^{37}$

Here are two more new rules: (1) no more claiming that mandatory arbitration is outcome neutral until that counterintuitive claim is proven by rigorous, methodologically sound research; and (2) stop contending that claim-suppressing arbitration is a good deal for "the many." Period. It is hard to believe that intelligent people can believe that argument. I can only assume, out of respect for the intellects of those who advance it, that they are being cynical and disingenuous. I've shown at length why this argument doesn't work. ${ }^{38}$ To begin with, why should legitimate high-cost/high-stakes claims be sacrificed as a bribe to induce corporate defendants to arbitrate low-stakes cases? Proponents of this argument never offer any moral or political justification for it beyond the insinuation that employment discrimination victims and consumer class action members are Cadillac-driving elitists. Second, where does anyone get the idea that claim-suppressing arbitration welcomes or attracts the filing of more claims, large or small? Simple microeconomics tells us that an employer will switch back to a litigation regime the moment it perceives that the cost of arbitrating many smaller "Saturn" claims exceeds the cost of litigating fewer "Cadillac" claims. That means the number of Saturns is necessarily capped, and "the many" may not be that many. Indeed, empirically, there is no support for the argument that arbitration is more accessible to "the many" than litigation. As a thrown-down gauntlet to interested researchers on this question, I have pulled together (admittedly loosely) some estimates suggesting that, controlling for the limited number of AAA mandatory arbitration clauses, employees are five times more likely to file their claims if they have access to a court than if they are forced to arbitrate with AAA.$^{39}$ Finally, if purveyors of this "Saturns for Cadillacs" argument were genuinely interested in the disputing rights of "the many," why have they never proposed an amendment to the FAA requiring arbitration of all small or "low-stakes" claims while allowing class actions and other "high-stakes" claims to go to court? Wouldn't that make everyone happy? Oh, right $—$ not the defendants, I guess.

What kind of a way is this to make a dispute-resolution law? The wealthy party - the employer or seller with the power to impose an adhesion contract-has the exclusive right to decide how disputes will be resolved. How can this possibly conform to due process? ${ }^{40}$ Claim-suppressing arbitration supporters justify the FAA with arbitrary, retrofitted rationalizations, including increased pressures to make

37. See id.; Sherwyn et al., supra note 3, at 1579-80; Sherwyn, supra note 3, at 30.

38. Schwartz, supra note 1, at 1315-33.

39. Id. at 1321-22. Indeed, my prior estimate, if anything, greatly overstates the extent to which employees choose arbitration over litigation in the first instance. The available AAA data did not distinguish between cases filed in arbitration as an initial matter from cases originally filed in court and compelled into arbitration under an arbitration clause. The number of arbitration filings are likely to include many of the latter, which of course do not indicate an employee's free choice of arbitration over litigation.

40. See Richard C. Reuben, Democracy and Dispute Resolution: Systems Design and the New Workplace, 10 HaRv. Negot. L. Rev. 11, 48-50 (2005); Richard C. Reuben, Democracy and Dispute Resolution: The Problem of Arbitration, 67 LAW \& CONTEMP. PROBS. 279 (2004). 
arbitration more like litigation, and by barely straight-faced reassurances that, despite the beliefs and intentions of claim-suppressing defendants, this arbitration system is really a better deal for claimants than litigation. ${ }^{41}$ The ordinary claimant whose interests we all bandy about did not have a say in the 1925 FAA enactment of a business-to-business dispute statute that did not directly concern them. ${ }^{42}$ They have had precious little say since the Supreme Court began to turn the statute against them in the early $1980 \mathrm{~s} .{ }^{43}$ Ordinary folks don't always win the legislative game, but, in this instance, they have never even been allowed to take the field.

\section{LOST IN THE DESERT: THE SUPREME COURT'S FAA JURISPRUDENCE}

The Supreme Court is as irretrievably lost in its arbitration jurisprudence as it has ever been in any line of cases in its troubled history. As Justice O'Connor famously put it, "[T]he Court has abandoned all pretense of ascertaining congressional intent with respect to the Federal Arbitration Act, building instead, case by case, an edifice of its own creation." ${ }^{44}$ Court majorities have reflected combinations of justices who are unwilling and those who are unable to undo the errors.

The broad pattern of Supreme Court decisions in this area has been one of confused decisions later gelling into clearly bad decisions. Confused decisions have been of two distinct types. The first involve procedural or jurisdictional issues of such hypertechnicality that the authors and readers of the opinion have difficulty in understanding how the decision tends to ratify a former, or pave the way for a future, bad decision. Moses H. Cohen ${ }^{45}$ - the patriarch of deeply confused FAA decisions-is the original case of this type; Vaden v. Discover Bank ${ }^{46}$ is the most recent. The second type of confused decision is one in which the Court consciously avoids a clear decision, finding some ground to dispose of the case that reserves the real issue for another day. Invariably, in the arbitration context, this too-clever-by-half practice leads to an exquisitely Delphic holding: Green Tree Financial Corp. v. Bazzle ${ }^{47}$ and Wright v. Universal Maritime ${ }^{48}$ are shining examples. Just as Wright, the confused decision, ultimately led to Pyett ${ }^{49}$ the bad

41. See Schwartz, supra note 1, at 1327-35; Schwartz, supra note 11, at 417-21.

42. See Schwartz, supra note 12 , at 76-78.

43. While pro-consumer or pro-employee amendments to the FAA have been kicking around in Congress since 1994, none has ever come to a floor vote in the House or Senate. See, e.g., Protection from Coercive Employment Agreements Act, S. 2012, 103d Cong. (2d Sess. 1994) (no Senate action outside committee). As argued below, the Supreme Court justices dissenting from FAA rulings supporting the pro-arbitration and pro-corporatedefendant positions, as well as the Court's liberal wing, have generally failed to articulate the consumer and employee stakes. See infra Part II.

44. Allied-Bruce Terminix Cos. v. Dobson, 513 U.S. 265, 283 (1995) (O’Connor, J., concurring).

45. Moses H. Cone Mem'l Hosp. v. Mercury Constr. Corp., 460 U.S. 1 (1982).

46. 129 S. Ct. 1262 (2009).

47. 539 U.S. 444 (2003).

48. 525 U.S. 70 (1998).

49. 14 Penn Plaza LLC v. Pyett, 129 S. Ct. 1456 (2009). 
one, so Bazzle will produce a bad decision in the much-anticipated case of AT\&T Mobility $v$. Concepcion, ${ }^{50}$ which will do away with the consumer/employee class action once and for all.

\section{A. Background}

The story of FAA jurisprudence since 1983 has been one of justices unwittingly backing themselves into an untenable position and then failing to perceive even a need to find a way out. Of the eighteen past and present justices who have participated in FAA decisions since 1983, only perhaps two (Stevens and O'Connor) showed any signs of having a clear idea of the stakes and implications of FAA decisions. The rest have been dense, inattentive, shortsighted, or opportunistic. As a result, there has not been the sort of clear and consistent "5-4" debate that has typically characterized analogous questions in which advocates of employee and consumer rights have been pitted against advocates of "tort reform." Only occasionally and haltingly have justices bothered to distinguish truly defendant-imposed arbitration from purely commercial pre-dispute arbitration agreements.

The willingness of characteristically liberal justices like Souter, Ginsburg, and Breyer to follow stare decisis uncritically, ${ }^{51}$ or to fall out into fragmented voting positions over obscure technical points, ${ }^{52}$ bespeaks a lack of understanding of how the decisions would affect the rights of generally disadvantaged litigants. One gets the impression that FAA cases-whose complexity is deceptive-simply could not command sufficient attention from key justices to figure out what any given holding would mean and where it would take the law.

I have written elsewhere of what I call the "Two Big Mistakes" of FAA jurisprudence. ${ }^{53}$ One error was the dismantling of what had become known as the "public policy exception" to the FAA. Two Supreme Court decisions, Wilko v. $S_{w a n}{ }^{54}$ and Alexander v. Gardner-Denver Co., ${ }^{55}$ and an influential Second Circuit decision, American Safety Equipment Corp. v. J. P. Maguire \& Co., ${ }^{56}$ had developed the doctrine that statutory claims "of great public interest"

50. 130 S. Ct. 3322 (2010) (granting certiorari).

51. See, e.g., Allied-Bruce Terminix Cos. v. Dobson, 513 U.S. 265, 280 (1995) (Breyer, J.) (Justices Stevens, Souter, Ginsburg, and Breyer voting to uphold the much-criticized, consumer-unfriendly decision in Southland Corp. v. Keating, 465 U.S. 1 (1984)); Doctor's Assocs., Inc. v. Casarotto, 517 U.S. 681 (1996) (Ginsberg, J.) (same); Buckeye Check Cashing, Inc. v. Cardegna, 546 U.S. 440 (2006) (Justices Stevens, Souter, Ginsburg, and Breyer voting to apply Prima Paint v. Flood \& Conklin Mfg. Co., 388 U.S. 395 (1967), to uphold arbitration against consumer interests).

52. See, e.g., Bazzle, 539 U.S. at 446 (noting that Justices Breyer, Scalia, Souter, and Ginsburg comprised the majority, joined by Justice Stevens in concurrence, and that Justices Rehnquist, O'Connor, Kennedy, and Thomas dissented).

53. Schwartz, supra note 11, at 406.

54. 346 U.S. 427 (1953).

55. 415 U.S. 36 (1974).

56. 391 F.2d 821 (2d Cir. 1968).

57. Id. at 827 . 
the Securities Act of 1933, the Civil Rights Act of 1964, and the Sherman Antitrust Act — could not be subject to compelled arbitration to prevent plaintiffs from taking these claims to court. ${ }^{58}$ Despite references in these cases to the rights of individual claimants, the gist of these holdings was the notion that arbitrators were narrow industry-or-trade specialists, often nonlawyers, and thus not sufficiently judicial in their craft and outlook to render decisions on complex and socially important statutory claims. The public policy exception cases did not stress, and indeed barely mentioned, the concept that these statutes all arose to regulate the overreaching party in a one-sided transaction and that it was therefore perverse to allow that regulated party to choose dispute resolution rules that it deemed advantageous, under the very nose of regulation.

That omission was unfortunate, for two reasons. First, the courts missed the opportunity to develop a theory and jurisprudence of claim-suppressing arbitration: that the FAA was not designed to enforce arbitration agreements in one-sided, regulated, contractual relationships. Second, the stated rationale for the public policy exception was predictably undermined as the ranks of arbitrators were increasingly filled by lawyers rather than trade professionals. ${ }^{59}$ It was thus easy for the Court to overrule the public policy cases without directly confronting-and perhaps, in the instance of some justices, without perceiving - the problem of claim suppression. Between 1985 and 1991, the Court overruled American Safety and Wilko and severely curtailed Alexander.$^{60}$ A central rationale for these rulings was stated in Mitsubishi: "[W]e are well past the time when judicial suspicion of the desirability of arbitration and of the competence of arbitral tribunals inhibited the development of arbitration as an alternative means of dispute resolution." 61

The other error was the decision in Southland Corp. v. Keating and its progeny ${ }^{62}$ to federalize arbitration law by holding that the FAA preempts state law. The manifold implications of this decision include making a needlessly complex hash of arbitration law by interpenetrating federal and state judge-made contract doctrine; creating a jurisdictional anomaly by holding the FAA to be the only "substantive" federal law that creates no federal question jurisdiction; inhibiting the states' efforts

58. Wilko, 346 U.S. at 435, and American Safety, 391 F.2d at 825, held that pre-dispute arbitrations were unenforceable for claims brought under the Securities Act and Sherman Antitrust Act, respectively. Alexander, 415 U.S. at 51-52, held that a labor arbitration could not preclude subsequent court litigation; though many lower courts construed Alexander to mean that a non-union, pre-dispute arbitration agreement was unenforceable as to Title VII claims. See Schwartz, supra note 12, at 93-94 \& n.242.

59. See Schwartz, supra note 12, at 94.

60. Mitsubishi Motors Corp. v. Soler Chrysler-Plymouth, Inc., 473 U.S. 614 (1985) (overruling American Safety, 391 F.2d 821); Rodriguez de Quijas v. Shearson/Am. Express, Inc., 490 U.S. 477 (1989) (overruling Wilko, 346 U.S. 427); Gilmer v. Interstate/Johnson Lane Corp., 500 U.S. 20 (1991) (overruling application of Alexander, 415 U.S. 36, to nonunion pre-dispute arbitration clauses).

61. Mitsubishi, 473 U.S. at 626-27; accord 14 Penn Plaza LLC v. Pyett, 129 S. Ct. 1456, 1470 (2009); Gilmer, 500 U.S. at 30; Rodriguez de Quijas, 490 U.S. at 481.

62. 465 U.S. 1 (1984); Circuit City Stores, Inc. v. Adams, 532 U.S. 105, 121-22 (2001) (rejecting argument that Southland Corp. v. Keating, 465 U.S. 1 (1983), be overruled); Doctor's Assocs., Inc. v. Casarotto, 517 U.S. 681 (1996) (reaffirming Southland Corp., 465 U.S. 1); Allied-Bruce Terminix Cos. v. Dobson, 513 U.S. 265 (1995) (same). 
to prevent misuse of arbitration clauses as loopholes in consumer protection law; and, of course, flouting the basic federalism principle, unanimously accepted by the Court in other contexts, that Congress cannot constitutionally make procedural rules for state courts. ${ }^{63}$

Here it is worth pausing to consider the handiwork of Justice Breyer. A member of the Court's liberal wing who presumably is inclined to take the side of employee and consumer rights claimants against the entrenched interests of corporate defendants, Justice Breyer brought powerful intellectual credentials to his job as justice. He had earned a great reputation, first as a law professor and then as an experienced appellate court judge. ${ }^{64}$ This means that he should have done better. I doubt whether any justice has been more unable to see the forest for the trees in any jurisprudential area in the Court's history than Justice Breyer in his arbitration opinions. $^{65}$

Justice Breyer wrote the majority opinion in Allied-Bruce Terminix Cos. $v$. Dobson ${ }^{66}$ the case which offered the last clear chance to overrule Southland. Allied-Bruce squarely raised the question of FAA preemption in a case in which amicus briefs on behalf of twenty state attorneys general urged that Southland be overruled. A nationwide pest-control company sought to enforce its adhesive arbitration clause against a consumer in Alabama, where adhesion arbitration agreements were presumptively unenforceable by statute. The stakes of the case, for arbitration law, would have been to allow states to regulate arbitration agreements in purely state law consumer protection cases. Instead of focusing on the implications for consumer and employment rights of imposing a federal pro-arbitration regime on adhesion contracts, the four liberal justices were apparently intent on deciding abstract federalism questions $a$ la the pending United States v. Lopez case (argued two months before Allied-Bruce was decided). ${ }^{67}$ This was a sad, pivotal moment in the history of FAA preemption: two justices (Thomas and Scalia) dissented and argued for overruling Southland on the grounds that the FAA did not apply to the states; a third (O'Connor) expressed the same view and concurred with great reluctance; and a fourth (Rehnquist) had dissented in Southland, but may have begun to see the opportunity to use the FAA as a

63. See Johnson v. Fankell, 520 U.S. 911 (1997); David S. Schwartz, The Federal Arbitration Act and the Power of Congress over State Courts, 83 OR. L. REV. 541 (2004).

64. See Stephen G. Breyer, OYEZ, http://oyez.org/justices/stephen_g_breyer; Biographies of the Current Justices of the Supreme Court, SuPREMECOURT.GOV, http://www.supremecourt.gov/about/biographies.aspx.

65. Justice Ginsburg has been a little better, routinely signing on to Justice Breyer's opinions.

66. 513 U.S. 265 (1995).

67. 514 U.S. 549 (1995). The Allied-Bruce majority could not see beyond the question of the scope of the commerce clause:

The pre-New Deal Congress that passed the Act in 1925 might well have thought the Commerce Clause did not stretch as far as has turned out to be the case. But, it is not unusual for this Court in similar circumstances to ask whether the scope of a statute should expand along with the expansion of the Commerce Clause power itself, and to answer the question affirmatively-as, for the reasons set forth above, we do here.

Allied-Bruce, 513 U.S. at 275. 
claim-suppressing device. One can't help but think that just one or two liberals could have swung the decision the other way, had they understood the stakes. ${ }^{68}$

That is water under the bridge. Allied-Bruce is relevant to my point here as an illustration of Justice Breyer's penchant, not only for missing the big picture in arbitration decisions, but for creating mind-boggling distinctions without a difference. See if you can understand this key passage in which Justice Breyer purports to explain when state law is, and when it is not, preempted by the FAA. I know I can't:

In any event, $\S 2$ gives States a method for protecting consumers against unfair pressure to agree to a contract with an unwanted arbitration provision. States may regulate contracts, including arbitration clauses, under general contract law principles and they may invalidate an arbitration clause "upon such grounds as exist at law or in equity for the revocation of any contract." 9 U.S.C. $§ 2$ (emphasis added). What States may not do is decide that a contract is fair enough to enforce all its basic terms (price, service, credit), but not fair enough to enforce its arbitration clause. The Act makes any such state policy unlawful, for that kind of policy would place arbitration clauses on an unequal "footing," directly contrary to the Act's language and Congress' intent. ${ }^{69}$

The last two sentences (beginning "What states may not do . . .") simply cannot mean what they say, because they make no sense. An arbitration agreement may be unfair even if its basic terms are fair. As I've observed elsewhere, "[A] consumer contract may establish a reasonable sales price, but provide that future disputes will be arbitrated in Borneo before a panel of arbitrators chosen by the seller, with the consumer to pay a $\$ 1$ million forum fee to arbitrate his claim."70 Why can't states regulate grossly unfair arbitration clauses in otherwise fair contracts? Moreover, the purported distinction between "general contract law" and targeted regulation of arbitration clauses is incoherent: unconscionability is a general doctrine but can only be meaningful in the context of a specific, unfair clause. Justice Breyer's distinction has bedeviled lower courts ever since. ${ }^{71}$

Justice Breyer's incomprehensible hairsplitting has contributed decisively to a third major problem in arbitration jurisprudence, that of expanding the power of arbitrators to determine their own jurisdiction - that is, to give arbitrators virtually unreviewable authority to decide "who decides." Justice Breyer's first foray into the "who decides who decides" question came in 1995 in First Options of Chicago, Inc. v. Kaplan ${ }^{72}$ where a professional stock trader suing his stock-clearing company argued that he had not agreed to arbitrate the dispute. Defining the substantive scope of the arbitration agreement as a question of "arbitrability,"

68. There is of course a direct line from the preemption holdings of Southland and Allied-Bruce to the decision to preempt state unconscionability doctrine in AT\&T Mobility v. Concepcion, 131 S. Ct. 1740 (2011), discussed infra in the Epilogue.

69. Allied-Bruce, 513 U.S. at 281.

70. Schwartz, supra note 63 , at 562 .

71. Id. at 568.

72. 514 U.S. 938 (1995). 
Justice Breyer's opinion for a unanimous Court held that the arbitrability question should be decided in the first instance by the court absent a "clear and unmistakable" agreement to submit that question - who decides arbitrability? - to the arbitrator. ${ }^{73}$ The opinion went on to suggest that this rule - the court decides arbitrability - is merely a default rule, which can be overridden by clear contractual language giving arbitrability decisions to the arbitrator. ${ }^{74}$

This ruling would be all well and good, provided that the Court would be able to maintain a clear understanding that "arbitrability" encompasses only the question of what substantive claims have been agreed to be submitted to arbitration. Other issues regarding enforcement of arbitration agreements-which might be called "validity" issues - are expressly reserved for courts presented with arbitration clause challenges, pursuant to FAA section $4{ }^{75}$ Validity might best be understood as going to the question of whether an arbitrator has been contractually brought into being at all — whether a valid arbitration agreement was formed, or whether a prima facie arbitration agreement is unenforceable due to contract defenses such as unconscionability. The problem is that these distinctions are fairly fine-grained, and the terms "arbitrable" and "arbitrability" sound naturally as though they mean "subject to" or "suitable for" arbitration - thereby encompassing validity. ${ }^{76}$ To complicate matters further, there remain issues in a gray area between substantive "arbitrability" of issues and the contractual "validity" of an arbitration agreement: What if the claimant missed a statute of limitations in filing an arbitration claim? What if the claimant seeks to certify an arbitral class?

Justice Breyer muddied up these issues in due course. In Howsam v. Dean Witter Reynolds, Inc., ${ }^{77}$ the defendant brokerage sought a court order enjoining a securities fraud claimant from going forward in arbitration on the ground that the arbitration claim was barred by the six-year statute of limitations provided in the National Association of Securities Dealers (NASD) arbitration rules. ${ }^{78}$ The case might have been resolved simply, without categorizing the question as one of "arbitrability," "validity," or any such difficult category. After all, it was undisputed that a valid arbitration agreement existed and that NASD rules applied; the only question was whether the dispute accrued within the limitations period. ${ }^{79}$ Whether one views such a question as factual or as a mixed question of fact and law, it is an affirmative defense to a concededly arbitrable claim rather than a basis to challenge the arbitrator's power to decide; it is thus plainly within the ambit of the arbitrator's decision. Lower courts had tripped themselves up, however, by

73. Id. at $993-94$.

74. Id.

75. "If the making of the arbitration agreement or the failure, neglect, or refusal to perform the same be in issue, the court shall proceed summarily to the trial thereof." Federal Arbitration Act, 9 U.S.C. $\S 4$ (2006).

76. "Linguistically speaking, one might call any potentially dispositive gateway question a 'question of arbitrability,' for its answer will determine whether the underlying controversy will proceed to arbitration on the merits." Howsam v. Dean Witter Reynolds, Inc., 537 U.S. 79, 83 (2002).

77. $I d$. at 79 .

78. Id. at 82-83.

79. Id. 
labeling statute of limitations questions as "arbitrability" questions merely because they are technical rather than merits defenses ${ }^{80}$ - even though courts have no trouble realizing that statute of limitations is a waivable, nonjurisdictional defense when such a defense is made in court. ${ }^{81}$

Rather than deciding the straightforward question straightforwardly, or laying down clear distinctions between threshold issues for the court as opposed to those for the arbitrator, Justice Breyer unhelpfully interjected further new terminology by introducing the concept of the "dispositive gateway question." 82 He then went on to suggest that "arbitrability" means

the kind of narrow circumstance where contracting parties would likely have expected a court to have decided the gateway matter, where they are not likely to have thought that they had agreed that an arbitrator would do so, and, consequently, where reference of the gateway dispute to the court avoids the risk of forcing parties to arbitrate a matter that they may well not have agreed to arbitrate. ${ }^{83}$

This classic Breyer "clarity" would not be so bad if the new term "gateway question" were understood as a subset of arbitrability - the scope of substantive issues assigned to the arbitrator. But the problem is that "gateway" sounds even broader, and more inclusive than "arbitrability" - so broad as to include any threshold question, even validity questions that had always been reserved for the court. Recall that "arbitrability" had always been a question presumptively for the court, but contractually assignable to the arbitrator through a "clear and unmistakable" assignment; in contrast, "validity" questions had never been held assignable to the arbitrator. By reconfiguring and thereby confusing arbitrability and validity questions, Justice Breyer in effect opened the door to adhesion contract terms that would purport to assign even questions like unconscionability of the arbitration clause to the arbitrator for decision. This is exactly what was to happen eight years later in the disastrous Rent-A-Center v. Jackson ${ }^{84}$ decision, discussed below.

But first, Justice Breyer would continue this process of unwittingly breaking down the distinction between validity and arbitrability questions. In Green Tree Financial Corp. v. Bazzle ${ }^{85}$ two separate consumer class actions were filed in the state courts of South Carolina against Green Tree Financial Corp., a nationwide consumer loan company with a penchant for sharp dealing. Green Tree successfully moved to compel arbitration of both cases; but to its chagrin, both cases wound up before the same arbitrator who certified them as class actions and awarded the

80. See, e.g., PaineWebber, Inc. v. Farnam, 870 F.2d 1286, 1289-91 (7th Cir. 1989); Hanes Corp. v. Millard, 531 F.2d 585, 598 (D.C. Cir. 1976), superseded by statute, 35 U.S.C. $§ 294$ (2002).

81. See, e.g., Eriline Co. S.A. v. Johnson, 440 F.3d 648, 653-54 (4th Cir. 2006); Cent. States, Se. \& Sw. Areas Pension Fund v. Safeway, Inc., 229 F.3d 605, 610 (7th Cir. 2000).

82. Howsam, 537 U.S. at 83.

83. Id. at $83-84$.

84. 130 S. Ct. 2772 (2010).

85. 539 U.S. 444 (2003). 
claimants approximately \$27 million in damages and attorneys' fees. The South Carolina Supreme Court rejected Green Tree's challenge to the class-wide arbitration procedure on the ground that class arbitration was permissible as a matter of state procedural law. ${ }^{86}$ The United States Supreme Court affirmed, producing a fragmented set of opinions whose end result was part Solomonic and part Delphic.

A four-justice plurality opinion by Justice Breyer reasoned that the issue of "whether [an arbitration] agreement forbids class arbitration" interpretation question for the arbitrator, and not for the South Carolina courts. ${ }^{88}$ Accordingly, the plurality - joined in the judgment by a reluctant Justice Stevensvacated the judgment of the South Carolina Supreme Court and remanded the case to allow the arbitrator to make this determination. ${ }^{89}$ According to Justice Breyer, "gateway" matters for the court to decide include "whether the parties have a valid arbitration agreement at all or whether a concededly binding arbitration clause applies to a certain type of controversy." $" 90$ But questions of "contract interpretation and arbitration procedures" ${ }^{\prime 91}$ are for the arbitrator-here, whether the arbitration should be a class action was a question of "what kind of arbitration proceeding the parties agreed to." $" 92$

Bazzle was a truly unfortunate opinion. It offered the opportunity for the court to clarify whether and when, as a matter of framework FAA law, class arbitrations are permissible. Instead, the two opinions forming the judgment merely imply, but do not expressly conclude, that class arbitration may be permissible over the objection of the drafting party; but they tell us nothing about whether an unambiguous class action ban would be enforceable. Rather than clarifying matters, Justice Breyer further develops his "gateway issues" approach to create yet another mystifying distinction - that between "a certain type of controversy" and the "kind of arbitration proceeding the parties agreed to. ${ }^{.93}$ The italics are in the original, but all the italics in the world cannot help me discern the difference between "kind" and "type." Nor does it help much to say that "contract interpretation and arbitration procedures" are for the arbitrator. The conjunction "and" destroys any hope of meaning, since any dispute over whether and how an arbitration agreement will be enforced will involve "contract interpretation." Even worse, Justice Breyer,

86. Id. at $447-50$.

87. Id. at 451 .

88. Id.

89. It seems probable at this juncture that the arbitrator would construe the contract to allow class actions, since the alternative would entail vacating his own class arbitration awards. See supra Part I.C.1. Although the arbitrator had himself certified a class action in one of the two consolidated cases, the Supreme Court observed that he did so only after the trial court had certified a class on the same issues in the Bazzle action. Bazzle, 539 U.S. at 449. Thus, "[o]n balance, there is at least a strong likelihood in Lackey as well as in Bazzle that the arbitrator's decision reflected a court's interpretation of the contracts rather than an arbitrator's interpretation." Id. at 454.

90. Id. at 452 .

91. Id. at 453 .

92. Id. (emphasis in original).

93. Id. at 452 (emphasis in original). 
in Bazzle, introduces a third category of threshold issues - those that are to be determined by the arbitrator in the first instance. Class arbitration falls into this category, but for reasons that do not meaningfully distinguish it from what used to be known as "validity" and "arbitrability" issues. The defendants, after all, argued that class actions are per se incompatible with arbitration at all, an argument demonstrating that the class action issue has elements of "validity" analysis. Bazzle thus contributes mightily toward a hopeless confusion of (1) enforcement issues that are always to be judicially determined; (2) "arbitrability" or "gateway" issues that are presumptively for the court to consider, but that are also assignable by "clear and unmistakable" contract language to the arbitrator; and (3) "questions of contract interpretation and arbitration procedure," also known as the "kind of arbitration proceeding the parties agreed to."

Anyone hoping to understand that distinction would have to make sense of Bazzle in light of PacifiCare Health Systems, Inc. v. Book, ${ }^{94}$ argued and decided while Bazzle was pending. Book, authored by Justice Scalia, presented the question of whether a consumer could be compelled to arbitrate his Racketeer Influenced and Corrupt Organizations Act (RICO) ${ }^{95}$ claim pursuant to an arbitration agreement that purported to strip the claimant's right to obtain punitive damages. Book thus raised an issue that cuts across arbitrability and validity lines. Viewed through the lens of unconscionability doctrine, the punitive damages remedy-stripping provision is a question of validity of the overall arbitration agreement, and therefore a question to be decided by the Court. But a remedy-stripping clause can also be viewed as an "arbitrability" question on the theory that it is intended to limit the arbitrator's power to hear claims creating a right to the stripped remedy-in Book, the right to recover punitive damages. That "arbitrability" question would also be for the court, unless it were "clearly and unmistakably" assigned to the arbitrator. Glossing over all this, the Court unanimously agreed not to decide anything: "[S]ince we do not know how the arbitrator will construe the remedial limitations, the questions whether they render the parties' agreements unenforceable and whether it is for courts or arbitrators to decide enforceability in the first instance are unusually abstract." ${ }^{, 96}$

The only clear rule emerging from the Court's 2002 term, giving us the trio of Howsam, Bazzle, and Book, is this: questions that cannot command a majority rationale are for the arbitrator.

Am I being unfair in laying this all on Justice Breyer? In Bazzle, it is likely that there were not five votes in agreement on these issues: the plurality consisted of Justices Breyer, Scalia, Souter, and Ginsburg. Justices Rehnquist, O'Connor, and Kennedy dissented on the argument that would later win over Justices Scalia and Thomas to capture a majority in Stolt-Nielsen: that class arbitration cannot be ordered where not expressly permitted by the arbitration agreement.

No, I do not think I'm being unfair. The problem is that Justice Breyer's sort of clever "Court politics" strategy_ punt the question to the arbitrator and leave the difficult issues for another day — was too clever by half.

94. 538 U.S. 401 (2003).

95. 18 U.S.C. $\S 1964(c)(1970)$.

96. Book, 538 U.S. at 407. 
And Justice Breyer's strategy has now blown up in our faces. As will be seen below, by turning every dispute over enforcement of an arbitration agreement into an impenetrably difficult issue, the Bazzle-Book approach-all hard questions are for the arbitrator - has naturally merged into what will be seen as the Rent-ACenter rule: all enforcement questions are for the arbitrator.

The liberals would have served the public better by carving out clear positions on what was at stake in arbitration cases over the past fifteen years. They can and should have articulated a theory under which the rules for bilaterally negotiated pre-dispute arbitration agreements between substantial commercial entities are different from claim-suppressing arbitration clauses. They should have identified claim suppression for what it is and stated their opposition to it, even in dissent. They should have articulated public policies - such as the broad public interest underlying class actions and damage remedies under "private attorneys general" statutes like RICO - that transcend the FAA. They should never have conceded that the availability of such important remedies, particularly class actions, are to be decided under judge-made FAA law rather than other doctrinal regimes. I blame Justice Breyer insofar as he is the author of several of these short-sighted, tactical, too-clever-by-half opinions - and, I suspect, the architect of the behind-the-scenes deals that produced them. But the entire liberal wing is to blame. Even in their dissenting opinions, they have consistently failed to say what is at stake for consumers and employees in these arbitration decisions. They have failed to see that their mincing, incremental steps in FAA cases were all steps backward.

\section{B. Recent Decisions: On the Brink of Adopting Claim Suppression}

Two of the Supreme Court's arbitration decisions from the 2009 term show the Court on the very brink of an explicit embrace of arbitration's claim-suppressing potential. They represent a new low point in the Court's FAA jurisprudence. But for the fact that arbitration law is something of a doctrinal backwater, whose implications are obscured by layers of procedural arcana, there would be a widespread sense that a truly Lochner-esque set of decisions is unfolding before our eyes.

Stolt-Nielsen S.A. v. AnimalFeeds International Corp. ${ }^{97}$ decided in April 2010, addressed the question "whether imposing class arbitration on parties whose arbitration clauses are 'silent' on that issue is consistent with the Federal Arbitration Act." ${ }^{\text {A }}$ A 5-3 majority rejected class arbitration. The plaintiff, AnimalFeeds International, is an animal-feed supplier that participated in a "charter party," a consortium of like business interests that contracts for shipping container space. The defendants, Stolt-Nielsen et al., are "shipping companies that serve a large share of the world market for parcel tankers." $"$ In this sense, the parties represent a classic picture of the kind of commercial relationship the FAA was intended to facilitate: substantial commercial entities of sufficient bargaining power to look after their own interests. The arbitration agreement was contained in a

97. 130 S. Ct. 1758 (2010).

98. Id. at 1764 (citation omitted).

99. Id. 
standard form used by the plaintiff's charter party, of which AnimalFeeds was a member. Nevertheless, it is hardly plausible to view the arbitration agreement as adhesive. The defendants apparently held sufficient market power to be a plausible target for antitrust litigation, which accounts for the underlying merits dispute. It is highly doubtful they could have been bullied into an unwanted arbitration clause. In the wake of a 2003 Justice Department investigation, which "revealed that [defendants] were engaging in an illegal price-fixing conspiracy," AnimalFeeds and other charterers filed suits in various U.S. district courts that were ultimately consolidated into a single class action. ${ }^{100}$ The Second Circuit held that the case must be submitted to arbitration. The parties entered into a supplemental agreement to submit to a panel of three arbitrators the question of whether the arbitration could proceed as a class action (under the AAA Class Rules), given that the arbitration agreement is "silent" on the issue of whether class arbitration is permissible. The arbitrators concluded that the arbitration agreement did indeed permit class arbitration, and the case went back to court to review that ruling. ${ }^{101}$

The Supreme Court rejected the arbitrators' decision, holding that "a party may not be compelled under the FAA to submit to class arbitration unless there is a contractual basis for concluding that the party agreed to do so." ${ }^{, 102}$ Recognizing that judicial review of arbitrators' decisions "must clear a high hurdle," 103 the Court concluded that the hurdle was cleared: the arbitrators "exceeded [their] powers" 104 within the meaning of FAA section 10(a)(4) by ordering class arbitration where neither the contract language permitted it nor any "default rule" supplied by the FAA, maritime law, or New York contract law allowed contractual silence to be construed to permit it. Instead the arbitration panel "imposed its own policy choice," which exceeded its powers since arbitrator's power to decide is a matter of contract, not public policy. ${ }^{105}$

The dissent, by Justice Ginsburg (joined by Justices Breyer and Stevens) was hardly a ringing endorsement of the public policies at stake. "The Court errs in addressing an issue not ripe for judicial review," thunders Justice Ginsburg. ${ }^{106}$ Since the parties had agreed to submit to the ruling of the arbitration panel, the class arbitration should have gone forward and have been subject to judicial review only afterward - perhaps wiping out an award based on years of costly arbitration proceedings. "Were I to reach the merits, I would adhere to the strict limitations the Federal Arbitration Act places on judicial review of arbitral awards."107 The dissenters thus endorse the Breyer approach of punting important questions to the arbitrator: "The arbitrators decided a threshold issue, explicitly committed to them." 108 Meanwhile, they make only a wan allusion to the public interest in class

100. Id. at 1765 .

101. Id. at $1764,1766$.

102. Id. at 1775 (emphasis in original).

103. Id. at 1766. The Court once again declined to "decide whether "manifest disregard"" is the proper standard for judicial review. Id. at 1768 n.3.

104. Id. at 1770.

105. Id.

106. Id. at 1777 (Ginsburg, J., dissenting).

107. Id. (citation omitted).

108. Id. at 1781. 
adjudication and the just-over-the-horizon assault on consumer class actions in the now-pending Concepcion case:

First, the Court does not insist on express consent to class arbitration.... Second, by observing that "the parties [here] are sophisticated business entities," and "that it is customary for the shipper to choose the charter party that is used for a particular shipment," the Court apparently spares from its affirmative-authorization requirement contracts of adhesion presented on a take-it-or-leave-it basis.... [T]hese qualifications limit the scope of the Court's decision.... ${ }^{109}$

Hardly. To be sure, aspects of the majority opinion leave the door ajar to a state law default rule that reads class arbitration into a silent arbitration clause. Yet it would take very little for the five-justice conservative majority to recast its holding as an FAA "federal common law" principle that "a party may not be compelled under the FAA to submit to class arbitration" 110 without its consent. This interpretation of the Stolt-Nielsen holding would preempt state law default rules, assuming there are any. Further, one would be unwise to overlook the majority's touching solicitude for the consent of the nondrafting party: "the [arbitrators'] conclusion is fundamentally at war with the foundational FAA principle that arbitration is a matter of consent." ${ }^{\text {"111 }}$ Perversely, it is only because the Stolt-Nielsen defendants were powerful enough to bargain over an arbitration clause, had they chosen to do so, that the Court will take the trouble to consider what they actually consented to. In contrast, the Court has had no trouble imposing "constructive consent" notions on parties too weak to bargain over an arbitration clause, concluding that they "consented" to arbitration and were not "coerced." The Court will protect a shipping company that serves a large share of the world market for parcel tankers from its bad arbitration "bargain," but not a credit card customer.

The big issue, never addressed in a Supreme Court majority, plurality, concurrence, or dissent, is whether a ban on class arbitration can be effective to ban class actions entirely. By implication, in the aftermath of Stolt-Nielsen, the plaintiffs will have to proceed, if at all, in individual arbitrations. The implacable logic of the Court's arbitration jurisprudence is that an arbitration agreement means that arbitration is the claimant's exclusive remedy; and if he can't proceed on a class basis in arbitration, he can't proceed on a class basis at all, since the courthouse door is closed. Despite the thin silver lining identified in the StoltNielsen dissent, the answer to this question is foreordained. If a party can refuse its

109. Id. at 1783 .

110. Id. at 1763 .

111. Id. at 1775; see also id. at 1773 ("[A]rbitration "is a matter of consent, not coercion."”); id. at 1774 ("Underscoring the consensual nature of private dispute resolution . ..."); id. at 1775 ("[C]lass-action arbitration changes the nature of arbitration to such a degree that it cannot be presumed the parties consented to it by simply agreeing to submit their disputes to an arbitrator."); $i d$. at $1775-76$ ("[T] he relative benefits of class-action arbitration are much less assured, giving reason to doubt the parties' mutual consent to resolve disputes through class-wide arbitration."). 
consent to class arbitration implicitly, by making no express agreement to class arbitration, why may it not do so explicitly, with a class action ban?

There are but two ways to escape this box. One is to create a public policy exception as a matter of FAA doctrine by which class actions may proceed in court over the defendant's objection, notwithstanding an arbitration agreement. If, as the Stolt-Nielsen majority reminds us, an arbitrator "has no general charter to administer justice for a community which transcends the parties," 112 then parties should retain access to the courts for class actions. These serve broad societal purposes beyond the interests of the named parties - interests that cannot be signed away in private, bilateral agreements.

Good luck with that one. It doesn't take a particularly close reading of Stolt-Nielsen to see that such an argument stands little chance with the five-justice majority, for whom the only cognizable policy is the "consent" manifested in the arbitration agreement, elevated to an overriding national policy under the FAA.

The other escape route is state unconscionability doctrine. As a matter of state law, an arbitration agreement banning class actions is unconscionable, and therefore unenforceable. As a result, the plaintiff has access to court, where of course a class action is available. This issue has been teed up in AT\&T Mobility v. Concepcion.

Before offering my prediction of the inevitably gloomy result, it is necessary to examine the other horrendous 2010 Supreme Court arbitration decision, Rent-ACenter v. Jackson. ${ }^{113}$ In Rent-A-Center, decided less than two months after StoltNielsen, the Court considered an arbitration agreement between the defendant-employer and the plaintiff-employee, Jackson, who filed an employment discrimination suit under 42 U.S.C. § 1981. When Rent-A-Center moved to compel arbitration, Jackson argued that the arbitration agreement was unconscionable under Nevada law. The district court compelled arbitration, relying on a clause in the agreement providing that " $[\mathrm{t}]$ he Arbitrator ... shall have exclusive authority to resolve any dispute relating to the ... enforceability ... of this Agreement including, but not limited to any claim that all or any part of this Agreement is void or voidable." 114 The Ninth Circuit reversed, holding that the threshold issue of unconscionability was for the court, not the arbitrator, despite the contractual assignment of the issue. ${ }^{115}$

The Supreme Court reversed. In an opinion that severely strains the concept of a "reasoned decision," a 5-4 majority per Justice Scalia held that the decision on the unconscionability of the arbitration clause was for the arbitrator. A straightforward approach to this question would have been to cite the Breyer line of arbitrability decisions to say that the parties are free to assign any question to the arbitrator by contract. But there is a conceptual problem there, one that might have pricked the conscience even of one or more of the majority justices. If an arbitration agreement is unconscionable, then the victim of the unconscionable contract never really agreed to arbitration at all —and there is no legal basis to authorize an arbitrator to

112. Id. at 1774 (quoting United Steelworkers v. Warrior \& Gulf Nav. Co., 363 U.S. 574, $581(1960))$.

113. 130 S. Ct. 2772 (2010).

114. Id. at 2775 .

115. Id. 
decide anything affecting that party's rights. To get around this problem, the majority relies on the rule of Prima Paint Corp. v. Flood \& Conklin Manufacturing. Co ${ }^{116}$ In Prima Paint, the Court held that arbitration clauses were "severable" from the rest of the contract containing them; and therefore, a claim that a contract was procured by fraud had to be submitted to arbitration, unless there was a contention that the arbitration agreement was voided due to fraud "directed to the arbitration agreement itself." Here, in Rent-A-Center, the Court extended this long-standing, albeit bizarre, doctrine to an unconscionability argument — adding an even more bizarre twist. Jackson's arbitration agreement with Rent-A-Center, the majority "reasoned," is a contract complete in itself: the "delegation provision," delegating the decision of unconscionability vel non to the arbitrator, is a specific clause within that arbitration contract. Under Prima Paint, the delegation clause is severable and enforceable when what is being challenged is the unconscionability of the arbitration "contract" as a whole. Therefore, the delegation clause stands, and the question of unconscionability must go to the arbitrator.

Justice Scalia and his four concurring brethren are not so stupid as to believe that this analysis makes any sense. There will never be occasion to challenge a delegation clause without challenging the overall arbitration clause: it is more or less a logical impossibility, because the delegation clause only comes into play when there is a challenge to arbitration. It is also fatuous to view the arbitration clause as a self-contained, stand-alone contract. Whether it was a separate document or part of a larger employment contract or job application doesn't matter; as the majority itself states, the arbitration agreement was signed "as a condition of his employment." 117 That means - and the majority justices know this- that the arbitration agreement is part of the employment contract. One could go on and criticize this particular application of the Prima Paint rule — but what's the point? Clearly, we have moved beyond the stage where doctrinal niceties will dictate decisions in this area. This is a purely result-driven case in which the majority was determined to send this case to arbitration. It could have quoted "Jabberwocky" as dispositive authority. It could have issued no "reasoned opinion" at all.

While it was nice to see the four liberal justices coming together to dissent, it is worth noting the various ways in which their protests are "too little, too late." The majority opinion gets more than halfway to its result by relying on Justice Breyer's "gateway jurisprudence" that embraces the notion that jurisdictional decisions can be contractually delegated to the arbitrator. It would have been useful, perhaps, had some of the liberals seeded a few of those opinions by suggesting some limits to the principle. In addition, the dissent jibes that "[i]n applying Prima Paint, the Court has unwisely extended a 'fantastic' and likely erroneous decision." ${ }^{\text {"118 }}$ To be sure, Prima Paint was a dubious decision - why should a party that procures a contract by fraud get any benefit of its bargain? On the other hand, in (lukewarm) defense of Prima Paint, it can be argued that fraudulent inducement claims are all too easily

116. 388 U.S. 395 (1967).

117. Rent-A-Center, 130 S. Ct. at 2775.

118. Id. at 2785 (Stevens, J., dissenting) (quoting Prima Paint, 388 U.S. at 407 (Black, J., dissenting)). 
alleged, and would have provided a gaping exception to enforcement of pre-dispute arbitration clauses; whereas, proof of such claims requires the sort of fact-intensive inquiry into business disputes that arbitrators are traditionally accustomed to. But whatever might be said for applying Prima Paint to its original context of fraud-in-the-inducement claims, the same does not apply to contracts that are voidable on grounds that are largely apparent on the face of the contract: illegality and unconscionability. In any event, three of the four dissenters-Justices Stevens, Breyer and Ginsburg-joined the majority in Buckeye Check Cashing v. Cardegna ${ }^{119}$ which extended the Prima Paint rule for the first time beyond the fraud context to uphold an arbitration agreement in a check-cashing contract that allegedly violated state criminal usury laws. As one consumer rights lawyer noted, the reasoning of Buckeye would uphold an arbitration provision in a murder-for-hire contract. ${ }^{120}$ One wonders what light bulb went off between Buckeye in 2006 and Rent-A-Center in 2010 that made the dissenters see Prima Paint's "fantastic" quality.

More glaring is the dissent's inability or unwillingness to perceive, and object, to the glaring implications of Rent-A-Center. Unless a delegation clause is assailable under this ruling, a properly drafted delegation clause strips the court of power to review any "gateway" issues concerning arbitrability or validity. Courts will have no choice but to compel arbitration in every case, irrespective of defects in the arbitration agreement. It will then be up to the arbitrators to determine how to respond to unconscionable and overreaching arbitration agreements.

Is there any basis for arguing that a delegation clause is unconscionable in a manner that, as Rent-A-Center purportedly requires, "[is] specific to the delegation provision" and not applicable to the rest of the arbitration clause? ${ }^{121}$ Why, yes there is. The due process problem I mentioned above also stinks of unconscionability: it is unconscionable to require the adhering party to submit a question to an adjudicator with a financial stake in deciding the question favorably to the contract drafter. ${ }^{122}$ The contract drafter wants the arbitrator to decide everything. The arbitrator makes money by deciding he has the power to decide the validity of the delegation clause, which in turn permits him to uphold the validity of the arbitration agreement and thereby make more money by conducting the arbitration on the merits. Conveniently, the "procedural" requirement of unconscionability (essentially, a requirement that the contract be one of adhesion) ensures that such a rule would apply in cases with a claim-suppressing structure, but not to truly "freely-negotiated" arbitration agreements. ${ }^{123}$

However, the chances for such an argument to succeed necessarily depend on the Court's willingness to base its decisions on the logical dictates of its own doctrinal pronouncements. Unfortunately, I think we're beyond that in the claim-

119. 546 U.S. 440 (2006).

120. Conversation with Paul F. Bland, attorney for respondents (Nov. 9, 2005).

121. Rent-A-Center, 130 S. Ct. at 2780.

122. Cf. Graham v. Scissor-Tail, Inc., 623 P.2d 165 (Cal. 1981) (stating that it is unconscionable to name arbitrator with financial ties to contract-drafter).

123. In the Orwellian world of adhesion contracts, with consent being a mere legal fiction to signify that the court finds the contract to be commercially reasonable, it is necessary to qualify consent in this way to make clear we are talking about the real kind of consent. 
suppressing arbitration area. It would be a simple matter to turn aside my unconscionability argument — perhaps by saying that the arbitrator's financial stake in the "who decides" question is too minimal to really create a bias; or perhaps by saying that the same unconscionability argument can be directed to the rest of the arbitration clause; or that if unconscionability arguments, even different ones, are directed to both a "delegation clause" and the rest of the arbitration clause, it's all for the arbitrator under Prima Paint. It hardly matters. Stolt-Nielsen and Rent-ACenter reveal a five-justice bloc that sees itself as unconstrained by such niceties as doctrinal logic and public policies that support claimants and class actions. Instead, we're in an end game in which the Court majority feels empowered-and reading the 2010 election returns perhaps is empowered - to make rulings whose only logic is to ensure that pre-dispute arbitration is claim suppressing.

In this setting, can there be any doubt how Concepcion will be resolved? StoltNielsen all but assures us that no party to an arbitration agreement can be sued in a class action without its (actual) consent. Rent-A-Center tells us that all enforceability questions concerning arbitration agreements are to be decided by arbitrators, with the sole exception of arbitral decisions to certify class claimsthose are to be reviewed and reversed under FAA $\S 10$. Arbitrators' decisions denying class actions will not be judicially reviewable; decisions granting class actions will be reviewed and reversed. Moreover, all the sorts of remedy-stripping arbitration clauses that have been struck down as unconscionable by courts will no longer be reviewable by courts. The bluff guarantee of the Mitsubishi Court twentyfive years ago, that courts will stand by to ensure that arbitration maintains "the substantive rights afforded by the statute, ${ }^{, 124}$ will no longer be true. Claimants will now depend on the virtually unreviewable good faith and kindness of arbitrators. ${ }^{125}$ This is the justice system created for us when the Supreme Court is in charge of revising what the Founders gave us. Let's hope that arbitrators are angels after all.

\section{CONCLUSION}

The standard account of United States history tells us that the "institution of slavery" was on its way out due to economic factors until the invention of the cotton gin made slave agriculture profitable again. Before now, questions have been raised about how widespread claim-suppressing arbitration is, and some have suggested that claim-suppressing arbitration is on the decline. ${ }^{126}$ Whether claim-suppressing arbitration has been declining, stagnating, or increasing, the

124. Mitsubishi Motors Corp. v. Soler Chrysler-Plymouth, Inc., 473 U.S. 614, 628 (1985).

125. Even if arbitrators are conscientious about declining to enforce remedy-stripping provisions in arbitration clauses, they have the option to excise the remedy-stripping terms and enforce the arbitration agreement; indeed they have the financial incentive to take this approach. Perversely, such an approach incentivizes experimentation with remedy-stripping agreements. See David S. Schwartz, Understanding Remedy-Stripping Arbitration Clauses: Validity, Arbitrability, and Preclusion Principles, 38 U.S.F. L. REV. 49, 67-69 (2003).

126. See, e.g., Christopher R. Drahozal \& Quentin R. Wittrock, Is There a Flight from Arbitration?, 37 HoFSTRA L. REV. 71, 71-76 (2008) (citing and then rebutting claims that pre-dispute arbitration use is on the decline). 
Supreme Court's endorsement of claim suppression should lead to a dramatic spike in its use. If, as appears, simply imposing an arbitration clause provides blanket immunity against class actions, the attractiveness of such clauses will increase dramatically. A renewed opportunity to experiment with other remedy-stripping devices - with the knowledge that a "Rent-A-Center delegation clause" will prevent judicial review-will also increase arbitration's attractiveness to would-be claim suppressors. In a word, the Supreme Court's latest "arbitration trilogy"-StoltNielsen, Rent-A-Center, and, next up, Concepcion-will be claim-suppressing arbitration's cotton gin.

EPILOGUE: MAY 2011

The Court handed down its decision in AT\&T Mobility v. Concepcion ${ }^{127}$ on April 27, 2011, a few months after the completion of the final draft of this Article. In a 5-4 decision, the Court upheld a class action ban in an arbitration agreement, holding that state law doctrines refusing to enforce arbitral class action bans as unconscionable are preempted by the FAA. The opinion presents an apparent ambiguity that may lead some to believe that the door remains slightly ajar to limit enforcement of class-action-banning arbitration clauses. But I read Concepcion as creating the worst-case scenario I predicted above. Over a decade ago, Professor Sternlight posed the question in a prophetic article title, "[A]s mandatory binding arbitration meets the class action, will the class action survive?"128 The Supreme Court has now answered this question, with the once-unthinkable "no." Absent salvation from the political branches, the class action for consumer and employment claims is dead.

In Concepcion, the plaintiffs were California residents who, as purchasers of cellular telephone service, claimed that they had been illegally charged thirty dollars in sales tax on cell phones that had been offered to them as "free." They filed a class action complaint in federal court in California, and the defendant AT\&T Mobility (ATTM) moved to compel arbitration. ${ }^{129}$ The arbitration agreement banned class claims against ATTM; ${ }^{130}$ it further provided that the

127. 131 S. Ct. 1740 (2011).

128. Sternlight, supra note 10 , at 1 .

129. Brief for Petitioner at 8, AT\&T Mobility LLC v. Concepcion, 131 S. Ct. 1740 (2011) (No. 09-893). I rely on the briefs for the case facts because the facts presented in the Supreme Court's opinion tend to obscure-my guess is, deliberately-the fact that the plaintiffs sought judicial class relief, not class-wide arbitration. See Concepcion, $131 \mathrm{~S}$. Ct. at 1744-45 (stating that the Concepcions filed a district court complaint that "was later consolidated with a putative class action ... The Concepcions opposed the motion, contending that the arbitration agreement was unconscionable and unlawfully exculpatory ... because it disallowed classwide procedures" (emphasis added)).

130. The agreement stated: "YOU AND AT\&T AGREE THAT EACH MAY BRING CLAIMS AGAINST THE OTHER ONLY IN YOUR OR ITS INDIVIDUAL CAPACITY, AND NOT AS A PLAINTIFF OR CLASS MEMBER IN ANY PURPORTED CLASS OR REPRESENTATIVE PROCEEDING.” Brief for Respondents at 3, AT\&T Mobility LLC v. Concepcion, 131 S. Ct. 1740 (2011) (No. 09-893). 
arbitrators had no power to conduct class arbitration, ${ }^{131}$ and that, if the class action ban were found unenforceable, the arbitration agreement as a whole would be "null and void." $" 132$ In other words, ATTM's plain goal was to eliminate class claims entirely, but if forced to defend a class action, ATTM made sure it would be contractually guaranteed the right to do so in court.

Plaintiffs opposed the motion to compel arbitration on the ground that the class action ban made the arbitration agreement invalid under California unconscionability doctrine. In Discover Bank v. Superior Court ${ }^{133}$ the California Supreme Court had sensibly held that a class action ban (that happened to be in an arbitration agreement) tends to work as an exculpatory clause, effectively immunizing the defendant from liability for widespread low-dollar-value consumer frauds whose stakes are insufficient to sustain claims by litigants individually; accordingly, class action bans were unconscionable under California contract law, whether or not in an arbitration agreement. ${ }^{134}$ The district court denied the motion to compel arbitration on the basis of Discover Bank, and the Ninth Circuit affirmed. ${ }^{135}$ According to the Ninth Circuit, the Discover Bank unconscionability rule was a general contract defense saved from preemption under FAA $\S 2$ as "grounds ... for the revocation of any contract." 136

The Supreme Court reversed, in an opinion that destroys consumer and employment class actions while seeming to take great pains to appear to be doing less than that. The apparent ambiguity arises from a dispute over the question presented by the case. The Court (both majority and dissent) granted certiorari on the question as framed by the petitioner:

Whether the Federal Arbitration Act preempts States from conditioning the enforcement of an arbitration agreement on the availability of particular procedures-here, class-wide arbitration — when those

131. Brief for Petitioner at 4-5, AT\&T Mobility LLC v. Concepcion, 131 S. Ct. 1740 (2011) (No. 09-893).

132. A "blowup" provision in the agreement stated that, if the class action ban were "found to be unenforceable, then the entirety of this arbitration provision shall be null and void.” Brief for Respondents at 3, AT\&T Mobility LLC v. Concepcion, 131 S. Ct. 1740 (2011) (No. 09-893).

133. 113 P.3d 1100 (Cal. 2005).

134. The Discover Bank court reasoned that when a class action waiver is found in a consumer contract of adhesion in a setting in which disputes between the contracting parties predictably involve small amounts of damages, and when it is alleged that the party with the superior bargaining power has carried out a scheme to deliberately cheat large numbers of consumers out of individually small sums of money, then ... the waiver becomes in practice the exemption of the party "from responsibility for [its] own fraud, or willful injury to the person or property of another." Under these circumstances, such waivers are unconscionable under California law and should not be enforced.

Id. at 1110 (quoting Cal. Civ. Code $§ 1668$ (1872)).

135. Laster v. AT\&T Mobility LLC, 584 F.3d 849 (9th Cir. 2009). The Concepcion case was consolidated with the Laster case at this stage.

136. See Laster, 584 F.3d at 857-58 (citing Federal Arbitration Act, 9 U.S.C. § 2 (1947)). 
procedures are not necessary to ensure that the parties to the arbitration agreement are able to vindicate their claims. ${ }^{137}$

In general, it is quite normal and unproblematic for the Court to grant certiorari on the question as framed by the petitioner. Nor is it grounds for complaint that a certiorari petitioner will try to pose the question in a light favorable to its case. The problem with this phrasing of the certiorari question is that it does not fairly encompass the issue presented by the litigation.

Whether an arbitration agreement can be found unenforceable because it excludes class-wide arbitration procedures, and whether the availability of class-wide arbitration is necessary to vindicate a plaintiff's claims, are beside the point. The real question is whether an arbitration clause's ban on class claims would be enforced to deprive a plaintiff of a class action remedy in court. The Discover Bank rule holds that an arbitration clause is unconscionable if it does that. Likewise, the proceedings below posed the issue as individual arbitration under the contract versus judicial class action. Class arbitration was never on the table in this case - plaintiffs and defendant both agreed they did not want class-wide arbitration proceedings. And the point of the unconscionable contract term here, as in Discover Bank, was that individual arbitration was being used to displace and preclude class litigation. The plaintiffs sought to bring the argument back to what was really at stake in the case in its issue statement:

When a class-action ban that is otherwise unenforceable under generally applicable contract law is embedded in an arbitration agreement, is the contract law preempted by the FAA? ${ }^{138}$

But the Court assiduously ignored this framing of the issue.

After an unconvincing stab at suggesting that a challenge to a class action ban is an attack on arbitration itself, the Concepcion majority returns to the crafty version of the cert question. The Court spends the rest of its opinion arguing that a rule "[r] equiring the availability of classwide arbitration interferes with fundamental attributes of arbitration" and is thus preempted by the FAA under the doctrine of obstacle preemption. ${ }^{139}$ By focusing on this version of the question, the Court manages to uphold the contractual class-action waiver without ever directly confronting the problem raised by such a holding: that its decision allows arbitration clauses to be used to create immunity from class actions and, therefore, from the many small-stakes consumer and employment claims that cannot feasibly be brought on an individual basis. Barring judicial class actions and leaving plaintiffs only with their individual claims does indeed deprive many plaintiffs of a remedy, since their claims are too small to pursue individually. To argue otherwise would require not only reversing prior Supreme Court class action precedent, but

137. Petition for a Writ of Certiorari, AT\&T Mobility LLC v. Concepcion, $131 \mathrm{~S}$. Ct. 1740 (2011) (No. 09-893); see also AT\&T Mobility LLC v. Concepcion, 130 S. Ct. 3322 (2010) (granting certiorari).

138. Brief for Respondents at i., AT\&T Mobility LLC v. Concepcion, 131 S. Ct. 1740 (2011) (No. 09-893).

139. AT\&T Mobility LLC v. Concepcion, 131 S. Ct. 1740, 1748 (2011). 
also making an argument of dubious persuasiveness that would be vulnerable to academic criticism and political attack.

Presumably, the majority thought it could destroy class actions more stealthily by framing the question as if the plaintiffs and the court below had sought to proceed in class action arbitration rather than, as was actually the case, class action litigation. The Court can only frame the question the way it did by assuming the very point in controversy: once an arbitration agreement is in place, it will be enforced in some fashion, and the only question is what that arbitration will look like, not whether the claims will go forward in court due to unenforceability of the arbitration agreement. The majority simply does not entertain the idea that a class action ban might make an arbitration agreement unenforceable so that the class claims could go forward in court.

To be sure, an argument could be made that an arbitration agreement banning judicial class actions avoids unconscionability if it allows for class-wide arbitration. Few, if any, courts have decided that question; the Supreme Court never has. The problem with that argument is that defendants, such as ATTM here, do not want to shift class actions from court to arbitration, but instead want to eliminate class actions entirely. Solicitous of these corporate interests, the Court majority follows up on its critique of class arbitration begun in Stolt-Nielsen. The most notable aspect of the determinative analysis is the extent to which it relies on the very sorts of attacks on arbitration that are supposedly improper under current, pro-arbitration doctrine. Arbitration procedures and arbitrators are not to be "entrusted with ensuring that third parties' due process rights are satisfied." 140 Arbitration's "absence of multilayered [judicial] review makes it more likely that errors will go uncorrected." litigation." 142 It is more than a little like Alice in Wonderland to see arguments long advanced by pro-consumer arbitration critics - even by me, even in this very Article - used by the Court to attack arbitration's inadequacies in order, then, to enforce an arbitration clause. All this, presumably, because the Court is unwilling to take the flack for holding in a clear, direct way that consumer and employee class claims can henceforth be contracted away.

One might grasp at a straw of hope by reading Concepcion to stop short of that holding: the case holds "only" that a state law rule is preempted if it requires class arbitrations to be permitted as a condition of enforcing an arbitration clause. But it is a stretch to read Concepcion in this way. The majority implies that an unconscionability rule against class action bans will be read as a rule "allow[ing] any party to a consumer contract to demand [class-wide arbitration] ex post."143 The Court simply does not acknowledge the existence of a rule that allows the consumer to demand class-wide litigation when there is an arbitration clause present.

The dissent by Justice Breyer is another disappointment, entirely in keeping with the flawed arbitration jurisprudence of the Court's liberal wing. Now of all

140. Id. at 1752 .

141. Id.

142. Id.

143. Id. at 1750. 
times is the occasion to stop pulling punches. A rousing funeral oration, a tribute to the class action as a crucial vehicle for the vindication of consumer and employee rights, would seem to be in order, something that could serve as a rallying point, at least for legislative rescue. But no, nothing like that. Instead, the dissent confines itself to an argument for the suitability of arbitration to handle class claims. ${ }^{144}$ It is as if the dissent thinks that, by not naming the grave result-the destruction of class actions by the majority decision-it will not be real. Again, in the name of clever tactics, Justice Breyer and the liberal wing sacrifice clarity and with it the chance to help solve the problem.

Consumer watchdogs have not been taken in by the Court's attempt to camouflage its sweeping attack on class actions. A new version of the Arbitration Fairness Act was introduced in the Senate by Senators Franken and Blumenthal, and in the House by Representative Johnson, the same day that Concepcion was announced. ${ }^{145}$ The newly created Consumer Financial Protection Bureau may also be scrutinizing the decision. ${ }^{146}$ One can only hope that the political branches can intercede to fix the Supreme Court's horrendous mistakes.

144. Id. at 1758-62 (Breyer, J., dissenting).

145. See Sens. Franken, Blumenthal, Rep. Hank Johnson Announce Legislation Giving Consumers More Power in the Courts Against Corporations, Al Franken U.S. SenATOR FOR MinN. (Apr. 27, 2011), http://franken.senate.gov/?p=press_release\&id=1466.

146. Daniel Fisher, After Arbitration Ruling, Watch Warren's Consumer Bureau, FORBES.COM (Apr. 27, 2011, 1:06 PM), http://blogs.forbes.com/danielfisher/ 2011/04/27/ after-arbitration-ruling-watch-warrens-consumer-bureau/. 